\title{
In-silico identification and differential expression of putative disease resistance-related genes within the collinear region of Brassica napus blackleg resistance locus LepR2' in Brassica oleracea
}

\author{
Mohammad Rashed Hossain ${ }^{1,2} \cdot$ Mostari Jahan Ferdous ${ }^{1}$. Jong-In Park ${ }^{1}$. Arif Hasan Khan Robin ${ }^{1,2}$. \\ Sathishkumar Natarajan ${ }^{1} \cdot$ Hee-Jeong Jung ${ }^{1} \cdot$ Hoy-Taek Kim ${ }^{1} \cdot$ III-Sup Nou ${ }^{1}$ (i)
}

Received: 25 July 2019 / Revised: 16 May 2020 / Accepted: 7 July 2020 / Published online: 19 August 2020

(C) The Author(s) 2020

\begin{abstract}
Blackleg disease, caused by Leptosphaeria maculans, greatly affects the production of cabbage (Brassica oleracea). However, definitive R-gene(s) are yet to be identified in this crop. In contrast, a number of R-loci have been identified in A- or $\mathrm{B}$-genome crops. Identification of few resistant cabbage genotypes indicates the presence of R-genes in this C-genome crop. High ancestral synteny between Brassica genomes suggests that the collinear regions of known A- or B-genome R-loci may also contain functional R-genes in the C-genome. Strong resistance was observed in the cotyledons of cabbage inbred line SCNU-98 against two L. maculans isolates, 03-02 s and 00-100 s. We investigated the collinear region of the Brassica napus blackleg resistance locus LepR2' in B. oleracea since both isolates of $L$. maculans contain corresponding avirulence genes. The locus was collinear to a $5.8 \mathrm{Mbp}$ genomic segment of B. oleracea chromosome C09 containing 13 genes that have putative disease resistance-related domains. High expression of genes Bo9g117290 and Bo9g111510 against isolate 00-100 s, and high expression of genes Bo9g126150 and Bo9g111490 against both isolates in the resistant-line SCNU-98 indicate their putative roles in blackleg resistance, which remained to be functionally verified. This work enhances our understanding of R-gene-mediated resistance to blackleg in cabbage.
\end{abstract}

Keywords Blackleg $\cdot$ Cabbage $\cdot$ LepR2' $\cdot$ Leptosphaeria maculans $\cdot$ LRR-RLK $\cdot \mathrm{qRT}-\mathrm{PCR} \cdot \mathrm{R}$-gene $\cdot$ Synteny

\section{Introduction}

Blackleg, a disease particularly devastating to canola, is also known to cause substantial economic damage to cabbage (Dilmaghani et al. 2010; Humpherson-Jones 1985;

Communicated by Inhwa Yeam.

Mohammad Rashed Hossain and Mostari Jahan Ferdous contributed equally to this work.

Electronic supplementary material The online version of this article (https://doi.org/10.1007/s13580-020-00271-5) contains supplementary material, which is available to authorized users.

Ill-Sup Nou

nis@sunchon.ac.kr; nis@scnu.ac.kr

1 Department of Horticulture, Sunchon National University, Suncheon, Jeonnam 57922, Republic of Korea

2 Department of Genetics and Plant Breeding, Bangladesh Agricultural University, Mymensing 2202, Bangladesh
Piliponytė-Dzikienè et al. 2015). The disease is caused by Leptosphaeria maculans (anamorph: Phoma lingam) around the world and by Leptosphaeria biglobosa, a comparatively less damaging species, in Asian countries (Zhang et al. 2014; Liu et al. 2014; Hong et al. 2009; Hao et al. 2015; Mendes-Pereira et al. 2003). Cabbage is an essential ingredient of the daily diet, either in fresh or processed form, in East Asian countries such as Korea, Japan, and China, where $37.8 \%$ of the world's total cabbage is produced (FAO Statistics Database 2017).

The possibility of invasion by the more aggressive $L$. maculans is a growing concern for the East Asian cabbage industry, since $L$. maculans was previously reported to spread in Canada and Poland, where only L. biglobosa was predominant (Liu 2008; Fitt et al. 2008). Further, both pathogenic species inhabit similar ecological niches and preference for the agro-climatic conditions of this region may be conducive to the establishment of L. maculans (Fitt et al. 2008; West et al. 2001). The complicated life cycle of the pathogen, its ability to reproduce both sexually and asexually 
(Rouxel and Balesdent 2005), multiple disease cycles in a single growing season ( $\mathrm{Li}$ et al. 2007), longer resting period (several years) in crop residues (West et al. 2001; Li et al. 2007), and substantial global diversity in the pathogenicity of L. maculans strains (Kutcher et al. 2011) make it difficult to control the disease via chemical and agronomic practices alone. Preventing the spread of L. maculans and the development of resistant cultivars are thus prioritized in these countries to safeguard both canola and cabbage industries (Zhang et al. 2014; van den Burg et al. 2008; Zhang and Fernando 2018).

Unlike rapeseed and canola, resistance to blackleg has not been extensively investigated in cabbage. Hence, sources of resistance to the disease are scarce in cabbage. Most of the R-loci against the disease have been identified in the A- or B- genomes of Brassica family crops (Balesdent et al. 2002; Bohman et al. 2002; Rimmer and van den Berg 1992; Chèvre et al. 1997; Christianson et al. 2006; Delourme et al. 2006; Delourme et al. 2004; Leflon et al. 2007; Marcroft et al. 2002; Pang and Halloran 1996; Plieske et al. 1998), while definitive R-loci/genes in C-genome crops such as cabbage are yet to be identified (Larkan et al. 2013; Robin et al. 2017). However, a few cabbage genotypes have been reported to show moderate resistance against the disease (Ananga et al. 2006; Badawy et al. 1991; Ferreira et al. 1992). Very recently, two Korean cabbage lines were found to be resistant at the cotyledon stage against two L. maculans isolates, 03-02 s and 00-100 s, which contain multiple avirulent genes (Robin et al. 2017). These findings suggest the presence of R-gene(s) in cabbage.

Functional analysis indicated that most plant R-genes usually contain several domains such as leucine-rich repeat (LRR), nucleotide-binding site (NBS), coiled-coil (CC), Toll/Interleukin-1 Receptor (TIR), receptor like protein kinase (RLK), F-box domain (FBD), and mitogen-activated protein kinase (MAPK), which have distinct roles in plant defence against phytopathogens (Larkan et al. 2013; Ellis et al. 2000; Liu et al. 2007; Meng and Zhang 2013; Meyers et al. 1999; Sekhwal et al. 2015; van den Burg et al. 2008). Since A-, B-, and C-genomes of Brassica family crops share common evolutionary history and high ancestral synteny, we hypothesized that functional disease resistance-related domain-containing genes may also be present within the collinear regions of known A- or B-genome R-loci in the C-genome (Cheng et al. 2014; Franzke et al. 2011; Chalhoub et al. 2014; Liu et al. 2014). Such approach has been used to identify candidate orthologous genes for Sclerotinia stem rot resistance, seed colour, seed oil content, yield, and efficiency traits in oilseed rape (B. napus) using the corresponding known loci of Arabidopsis thaliana (Ding et al. 2012; Stein et al. 2013; Wu et al. 2013; Zhao et al. 2012). In the case of blackleg resistance, Yu et al. (2013) tracked the collinear region of B. napus blackleg resistance locus LepR4 in $B$. rapa and identified four putative disease resistancerelated NBS-encoding genes. We have investigated the $B$. rapa R-loci Rlm1, Rlm2/LepR3,LepR1, and LepR4 from the A-genome against the $\mathrm{C}$-genome (Nou IS, unpublished data). Here, we report disease resistance-related functional domain-containing genes within the collinear region of $B$. napus blackleg resistance locus LepR2' in the C-genome of $B$. oleracea along with their putative roles in blackleg resistance in cabbage, determined via differential expression analysis in contrastingly resistant cabbage lines against two L. maculans isolates.

\section{Materials and methods}

\subsection{In-silico analysis of the collinear region of $B$. napus blackleg resistance locus LepR2' in $B$. oleracea}

The collinear region of $B$. napus blackleg resistance locus LepR2' was identified in the B. oleracea genome (ensembl database) using the homologous segments of $B$. napus clones that contain the LepR2' flanking markers $s N 3888 F a$ and $s R 6903 a$ (Yu et al. 2012). Sequences of all the genes within this collinear region in B. oleracea were retrieved. The genes which contained putative functional disease resistance-related domains such as NBS, LRR, CC, TIR, MAPK, FBD, RLK, and RLP were identified using the Simple Modular Architecture Research Tool (http://smart .embl-heidelberg.de/) and the Conserved Domain Database Tool (https://www.ncbi.nlm.nih.gov/cdd/). MEME suite version 5.0.5 (http://meme-suite.org/tools/meme) was used to analyse the conserved motifs in the proteins encoded by these genes. Distribution of exons and introns of these genes were analyzed using the Gene Structure Display Server (GSDS2.0) web tool (http://gsds.cbi.pku.edu.cn/). The microsynteny relationship of these identified putative disease resistance-related genes with B. rapa, B. nigra, and A. thaliana were visualized via Circos v0.69.

\subsection{L. maculans isolates and preparation of inoculum}

L. maculans isolates $00-100 \mathrm{~s}$ and $03-02 \mathrm{~s}$, possessing multiple avirulence genes, were cultured on V8 agar media (20\%) at $22{ }^{\circ} \mathrm{C}$ and $16 \mathrm{~h}$ day length under fluorescent light for several weeks. Fungal spores were suspended in $10 \mathrm{~mL}$ sterile distilled water by scrapping the spores off culture plates with a sterile glass slide prior to collecting the spores by filtering the suspension with sterile Miracloth (EMD Millipore Corporation, USA). The spore concentration was adjusted to $2.25 \times 10^{7}$ spores $\mathrm{mL}^{-1}$ using sterile distilled water prior to inoculation. 


\subsection{Plant materials: inoculation and assessment of disease resistance}

Seeds of two Korean cabbage inbred lines, SCNU-72 and SCNU-98, were germinated in multi-pot trays using cocopeat soil in a growth chamber at $24 \pm 2{ }^{\circ} \mathrm{C}, 65 \%$ relative humidity, and a 16/8 h (light/dark) photoperiod under $420 \mu \mathrm{mol}$ photons $\mathrm{m}^{-2} \mathrm{~s}^{-1}$ light intensity at bench level. After 12 days of germination, the center of each cotyledon lobe was punctured with a sterile needle prior to inoculation with $10 \mu \mathrm{L}$ of the spore suspension. The disease responses were evaluated at 10 days post-inoculation (dpi) using a disease rating scale of $0-9$ following the procedures described in Robin et al. (2017).

\subsection{RNA Extraction and CDNA synthesis}

Total RNA was extracted from control $(0 \mathrm{~h})$, mock-, and pathogen-inoculated cotyledons of resistant and susceptible cabbage lines at $6 \mathrm{~h}, 24 \mathrm{~h}$, and $48 \mathrm{~h}$ using an 'RNeasy mini kit' (Qiagen, CA, USA). RNA purity and concentration were determined using a Nanodrop-2000 (Nanodrop Technologies, Wilmington, DE, USA). First-strand cDNA was synthesized from the extracted total RNA using 'SuperScript-III First-Strand Synthesis SuperMix' (Invitrogen, CA, USA) as per the manufacturer's guideline.

\subsection{Expression analysis by qRT-PCR}

Expression of the identified putative disease resistancerelated domain (e.g., LRR, CC, FBD, CC, MAPK and RLK) containing genes within the LepR2' collinear region in $B$. oleracea were analyzed by qRT-PCR in a Roche LightCycler ${ }^{\circledR} 96$ System (Roche Applied Science, Penzberg, Germany). Gene-specific primers were designed using 'Primer3Plus'. For each gene, the qRT-PCR reaction was performed with $5 \mu \mathrm{L}$ of $2 x$ qPCRBIO SyGreen Mix LoROX (PCR Biosystems, London, UK), $1 \mu \mathrm{L}$ of forward and reverse primers each ( $10 \mathrm{pmol}), 2 \mu \mathrm{L}$ of ultra-pure water, and $1 \mu \mathrm{L}$ of template cDNA $\left(60 \mathrm{ng}^{-1} \mathrm{~L}^{-1}\right)$ in a final reaction volume of $10 \mu \mathrm{L}$. The reaction condition was as follows: initial denaturation at $95{ }^{\circ} \mathrm{C}$ for $5 \mathrm{~min}, 45$ cycles of denaturation at $95^{\circ} \mathrm{C}$ for $10 \mathrm{~s}$, annealing at specific temperatures for $10 \mathrm{~s}$, and amplification and signal acquisition at $72{ }^{\circ} \mathrm{C}$ for $30 \mathrm{~s}$. Each biological replicate was tested with three technical replicates. Relative expression levels were quantified by the $2^{-\Delta \Delta \mathrm{Ct}}$ method using the mean of three actin genes as the internal control.

\subsection{Statistical analysis}

Statistical significance was tested using analysis of variance (ANOVA) and mean separation was performed using
Tukey's pairwise comparison in Minitab (v18) (Minitab Inc., State College, PA, USA).

\section{Results}

\subsection{Disease responses of cabbage lines to $L$. maculans isolates}

Significantly different responses to the two L. maculans isolates, $03-02 \mathrm{~s}$ and $00-100 \mathrm{~s}$, were observed in the inoculated cotyledons of cabbage inbred lines SCNU-72 and SCNU98 (Fig. 1a, b). At 10 dpi, the disease scores against both 00-100 s and 03-02 s isolates ranged from 7 to 8 in the line SCNU-72, having 70\% and $80 \%$ diseased cotyledon areas, respectively. In contrast, the disease scores in the line SCNU-98 ranged between 2-3 and 2-4 against these isolates, respectively, while having less than $30 \%$ diseased cotyledon area. This indicates that line SCNU-98 is resistant against both $L$. maculans isolates, $00-100 \mathrm{~s}$ and $03-02 \mathrm{~s}$. At $30 \mathrm{dpi}$, overall blackening of the stems of the susceptible line SCNU-72 was observed, whereas the stems of the resistant line SCNU-98 appeared healthy (Fig. 1c).

\subsection{Collinear region of $B$. napus blackleg resistance locus LepR2' in B. oleracea}

BLAST search of the sequences of the clones containing the flanking markers $s N 3888 F a$ and $s R 6903 a$ of B. napus blackleg resistance locus LepR2' identified a $5.8 \mathrm{Mbp}$ genomic segment of chromosome C09 (C9:36168200$41971165)$ as the corresponding collinear region in the $B$. oleracea genome (Fig. 2a, b). This region was flanked by genes Bo9g111470 and Bo9g135890. Mining this collinear region identified a total of 661 genes. The complete list of these 661 genes and their functional annotations are shown in Supplemental Table S1.

\subsection{Identification of genes containing disease resistance-related functional domains}

Functional domain analysis of the 661 genes identified 13 genes as having putative disease resistance-related domains (Table 1; Table S2). Five different putative disease resistance-related domains, namely leucine rich repeat (LRR), coiled-coil (CC), F-box domain (FBD), mitogen-activated protein kinase (MAPK), and receptor-like kinase (RLK) were identified within these 13 genes. Among these, 11 genes contained two domains, an LRR domain and either a FBD, MAPK, or a RLK domain; two genes contained only one domain, including Bo9g120720 (LRR domain) and Bo9g 135700 (CC domain). A domain-wise list of the selected 13 genes is shown in Table 2 and the domain 
Fig. 1 Disease symptoms (a) and scores (b) at 10 days post inoculation (dpi) against $L$. maculans isolates 03-02 $\mathrm{s}$ and 00-100 s at the cotyledon stage and disease (blackened stems) symptoms (c) at $30 \mathrm{dpi}$ against isolate 03-02 s in the stems of the seedlings of cabbage inbred lines SCNU-72 and SCNU98. Cotyledons of 12-day-old seedlings were inoculated and disease scores were recorded at 10 dpi. Data of five replicates are presented as a range, with green diamond shape indicating median values. $* * * p<0.001$ (one-way ANOVA with Tukey's multiple comparison test).

Blackened stem is indicated by red arrow
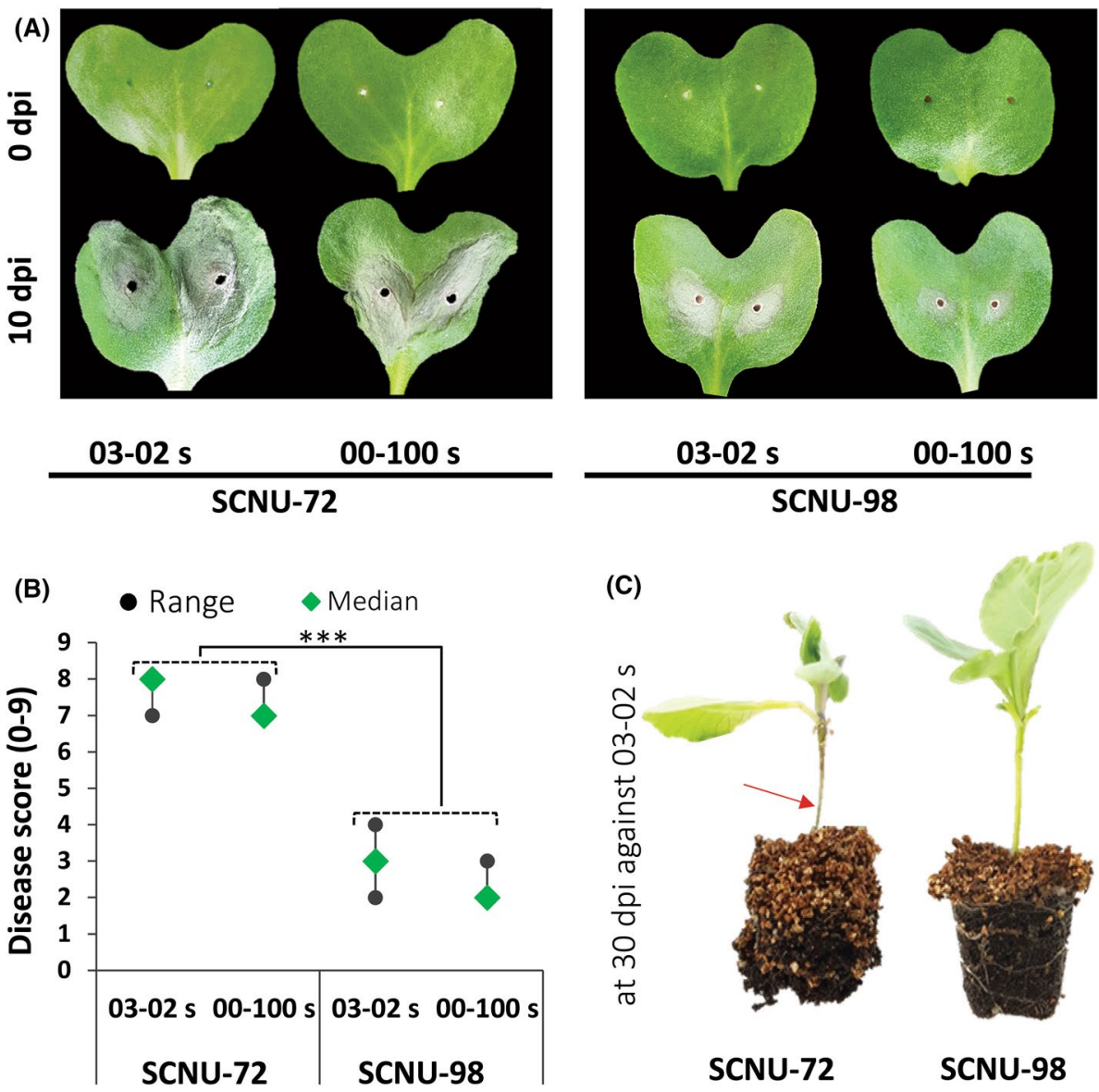

(C)

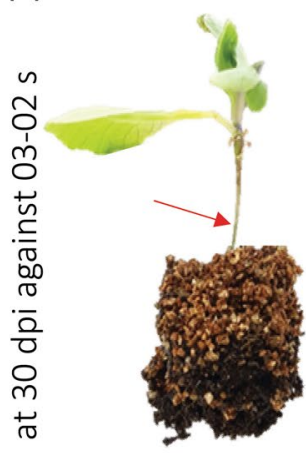

SCNU-72
00-100 s SCNU-98

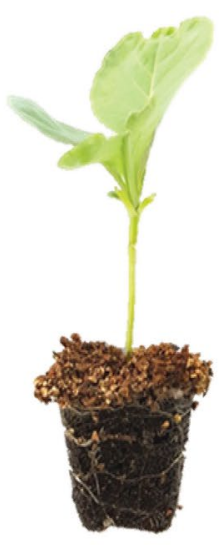

SCNU-98
(A) LepR2' on Brassica napus linkage group A10 (Yu et al., 2012)

cM Markers

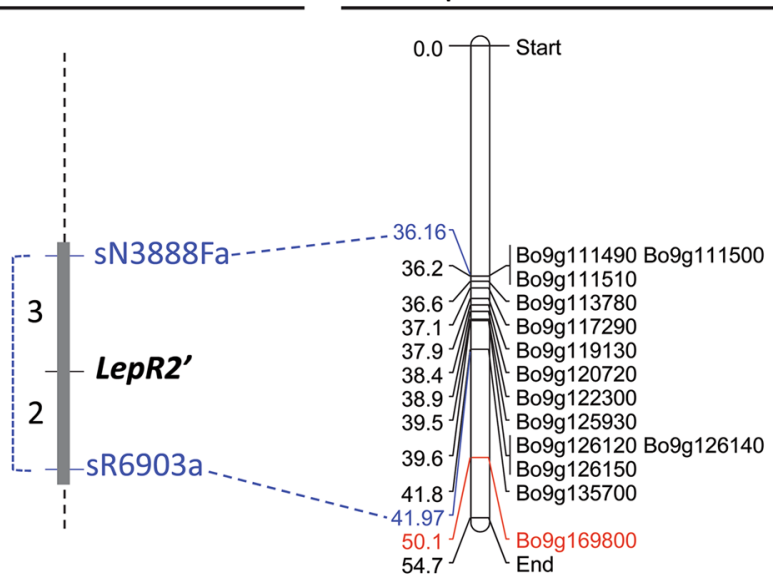

(B) Collinear region on Brassica oleracea chromosome $\mathrm{CO}$
(C) Microsynteny of LepR2' syntenic LRR, $\mathrm{CC}$ and RLP genes of $B$. oleracea with $A$. thaliana, B. rapa and B. nigra

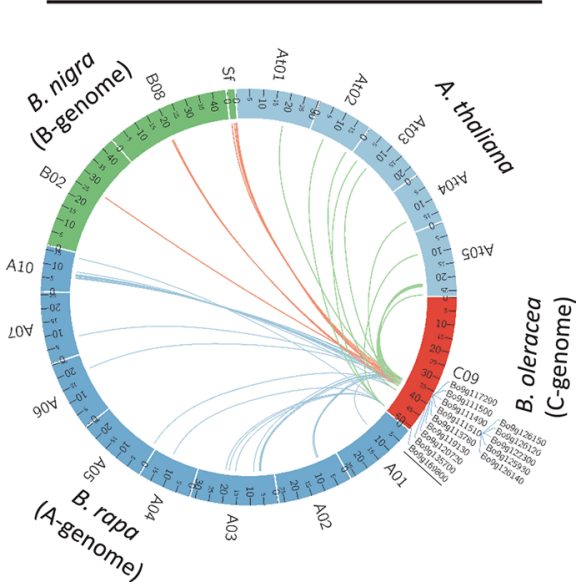

Fig. 2 Collinear region of B. napus blackleg resistance gene LepR2' (a) on B. oleracea chromosome $\mathrm{C} 09$ (b) and microsynteny relationship of the LRR, CC, FBD, MAPK, and RLK genes within the LepR2' collinear region of B. oleracea with A. thaliana, B. rapa, and $B$. nigra (c). Broken lines between the B. napus markers (a) and $B$. oleracea genes (b) indicate homologous genomic sequences. cM, centimorgan; Mbp, mega base pair; sf. B. nigra scaffold. The gene
Bo9g169800 (indicated by red text in figure B and by an underline in figure C) is not within the LepR2' collinear region (located $8.15 \mathrm{Mbp}$ apart). This gene is included for expression analysis, since it is orthologous to the cloned gene JX880110 (of B. napus blackleg resistance locus LepR3). The chromosomal location and microsynteny relations of this gene are shown, but not discussed in the results section 
Table 1 List of LRR, CC, FBD, MAPK, and RLK domain-containing genes identified within the collinear region of $B$. napus blackleg resistance gene LepR2' in B. oleracea

\begin{tabular}{|c|c|c|c|c|c|c|c|c|}
\hline SL. & Gene ID & $\begin{array}{l}\text { Chromosomal loca- } \\
\text { tion (strand) }\end{array}$ & CDS (bp) & Protein (AA) & Bolbase ID & Arabidopsis hit/e-value & Trembl ID & Description \\
\hline 1 & Bo9g111490 & $\begin{array}{l}\text { C9:36205987- } \\
36206796(+)\end{array}$ & 612 & 203 & Bol012300 & AT1G51370/3.2e-48 & A5BU14 & $\begin{array}{l}\text { F-box/FBD/LRR- } \\
\text { repeat protein }\end{array}$ \\
\hline 2 & Bo9g111500 & $\begin{array}{l}\text { C9:36207783- } \\
36209300(+)\end{array}$ & 1350 & 449 & Bol038356 & AT5G25850/1.3e-133 & A0MEF3 & $\begin{array}{l}\text { Putative F-box/FBD/ } \\
\text { LRR-repeat protein }\end{array}$ \\
\hline 3 & Bo9g111510 & $\begin{array}{l}\text { C9:36225550- } \\
36226914(+)\end{array}$ & 1095 & 364 & Bol045667 & AT5G53840/1.9e-94 & Q9M371 & $\begin{array}{l}\text { F-box/FBD/LRR- } \\
\text { repeat protein }\end{array}$ \\
\hline 4 & Bo9g 113780 & $\begin{array}{l}\text { C9:36563098- } \\
36566127(+)\end{array}$ & 3030 & 1009 & Bol038795 & AT5G53890/0 & C0LGV8 & $\begin{array}{l}\text { Leucine-rich repeat } \\
\text { receptor-like protein } \\
\text { kinase }\end{array}$ \\
\hline 5 & Bo9g120720 & $\begin{array}{l}\text { C9:38409782- } \\
38411047(-)\end{array}$ & 1266 & 421 & Bol018194 & AT5G66330/0 & Q9FH56 & $\begin{array}{l}\text { Leucine-rich repeat } \\
\text { (LRR) family } \\
\text { protein }\end{array}$ \\
\hline 6 & Bo9g122300 & $\begin{array}{l}\text { C9:38921557- } \\
\text { 38924901(+) }\end{array}$ & 3264 & 1087 & Bol006253 & AT5G56040/0 & Q2V2Y1 & $\begin{array}{l}\text { Leucine-rich receptor- } \\
\text { like protein kinase } \\
\text { family protein }\end{array}$ \\
\hline 7 & Bo9g125930 & $\begin{array}{l}\text { C9:39471679- } \\
39472702(-)\end{array}$ & 843 & 280 & Bol007650 & AT3G56780/1.1e-51 & Q9XEG1 & $\begin{array}{l}\text { FBD, F-box \& LRR } \\
\text { domains containing } \\
\text { protein }\end{array}$ \\
\hline 8 & Bo9g126120 & $\begin{array}{l}\text { C9:39616439- } \\
\text { 39618336 (+) }\end{array}$ & 1641 & 546 & Bol009927 & AT5G56560/4.4e-99 & A0MFP8 & $\begin{array}{l}\text { FBD, F-box \& LRR } \\
\text { domains containing } \\
\text { protein }\end{array}$ \\
\hline 9 & Bo9g126140 & $\begin{array}{l}\text { C9:39646902- } \\
39648088(+)\end{array}$ & 768 & 255 & Bol009927 & AT5G56560/3.5e-71 & A0MFP8 & $\begin{array}{l}\text { FBD, F-box and LRR } \\
\text { domains containing } \\
\text { protein }\end{array}$ \\
\hline 10 & Bo9g119130 & $\begin{array}{c}\text { C9:37855517- } \\
37856887(-)\end{array}$ & 1371 & 456 & Bol039693 & AT5G55090/0 & - & $\begin{array}{l}\text { Mitogen-activated } \\
\text { protein kinase } \\
\text { kinase kinase } 15\end{array}$ \\
\hline 11 & Bo9g126150 & $\begin{array}{l}\text { C9:39648887- } \\
39649535(-)\end{array}$ & 339 & 112 & Bol009929 & AT5G56580/1.7e-70 & B9RKG0 & $\begin{array}{l}\text { Mitogen-activated } \\
\text { protein kinase } \\
\text { kinase } 6 \text { (MAPK6) }\end{array}$ \\
\hline 12 & Bo9g135700 & $\begin{array}{l}\text { C9:41809830- } \\
\text { 41811526(-) }\end{array}$ & 1353 & 450 & Bol036595 & AT2G42480/1.8e-79 & Q9SLB4 & $\begin{array}{l}\text { MATH \& coiled-coil } \\
\text { (CC) domain-con- } \\
\text { taining protein }\end{array}$ \\
\hline 13 & Bo9g117290 & $\begin{array}{l}\text { C9:37066960- } \\
37069527(-)\end{array}$ & 2568 & 855 & Bol038854 & AT5G54380/0 & Q9LK35 & $\begin{array}{l}\text { Receptor-like protein } \\
\text { kinase THESEUS } 1\end{array}$ \\
\hline
\end{tabular}

FBD, F-box domain; LRR, Leucine Rich Repeat; CC, coiled-coil domain; MAPK, Mitogen-activated protein kinase domain

Table 2 Functional domain-wise classification of the LRR, CC, FBD, MAPK, and RLK genes within the collinear region of $B$. napus blackleg resistance locus LepR2' in B. oleracea

\begin{tabular}{lll}
\hline SL & Domain & Gene ID \\
\hline 1 & LRR & Bo9g120720 \\
2 & LRR-FBD & Bo9g111490, Bo9g111500, Bo9g111510, \\
& & Bo9g125930, Bo9g126120, \\
& & Bo9g126140 \\
3 & LRR-RLK & Bo9g117290, Bo9g113780, Bo9g122300 \\
4 & LRR-MAPK & Bo9g119130, Bo9g126150 \\
5 & CC & Bo9g135700 \\
\hline
\end{tabular}

LRR, Leucine Rich Repeat; FBD,F-box domain; CC, coiled-coil domain; RLK, Receptor like kinase; MAPK, Mitogen-activated protein kinase domain distribution along the length of these genes is shown in Fig. 3.

Conserved motif analysis of the selected 13 genes identified 15 statistically significant conserved motifs consisting of 18-50 amino acids (Fig. 4a; Table S3). Among these 15 motifs, 10 of the motifs were associated with LRR domains, while three (namely, motifs 2, 8, and 12) and two (namely, motifs 1 and 4) were associated with MAPK and FBD domains, respectively (Table S3).

Gene structure analysis identified the distribution of exons and introns in the selected 13 genes. Among these genes, a maximum of four exons were found in genes Bo9g111510, Bo9g126150, and Bo9g135700, while four genes (Bo9g113780, Bo9g120720, Bo9g119130, and Bo9g117290) contained only one exon (Fig. 4b). 
Fig. 3 Domain organization of the LRR, CC, FBD, MAPK, and RLK genes within the collinear region of $B$. napus blackleg resistance gene LepR2' in $B$. oleracea FBD $=\mathrm{F}$-box domain; LRR = Leucine Rich Repeat; CC, coiled-coil domain; STKc-IRAK, Serine/Threonine kinases, Interleukin-1 Receptor Associated Kinases; MAPK, Mitogen-activated protein kinase domain

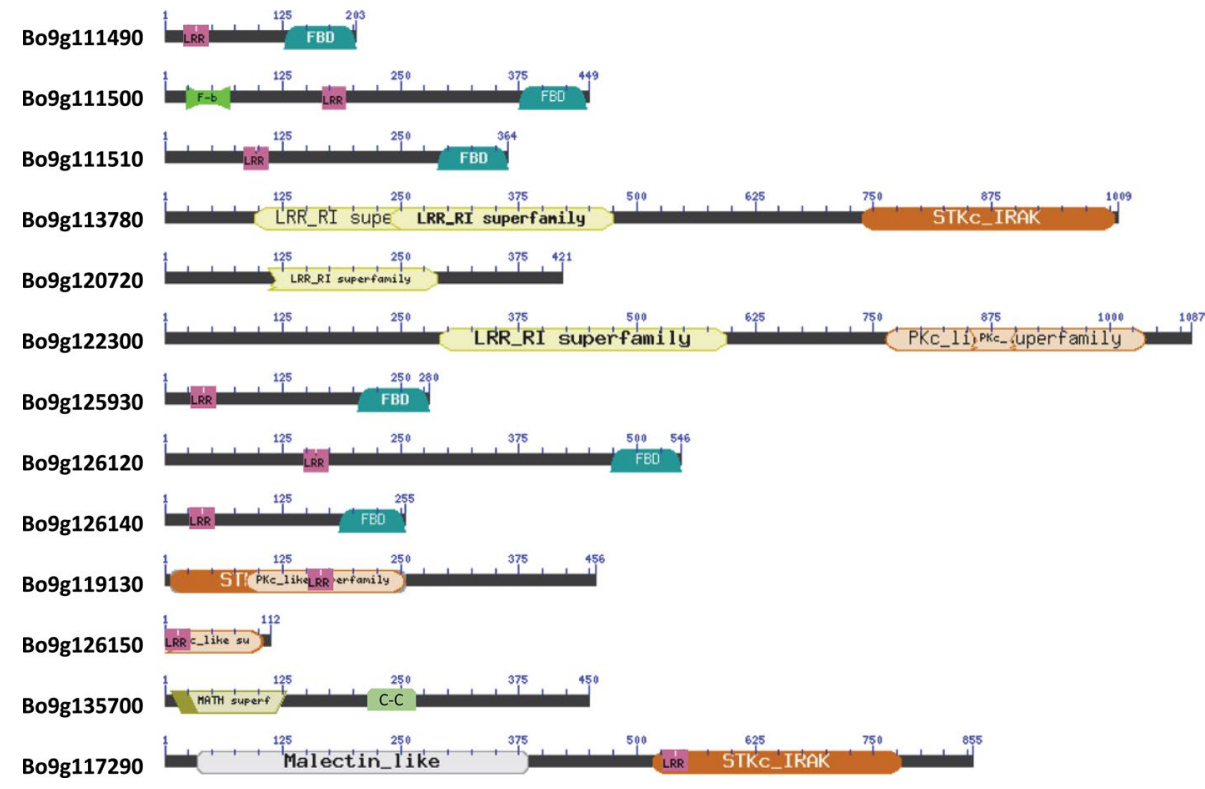

\section{(A)}

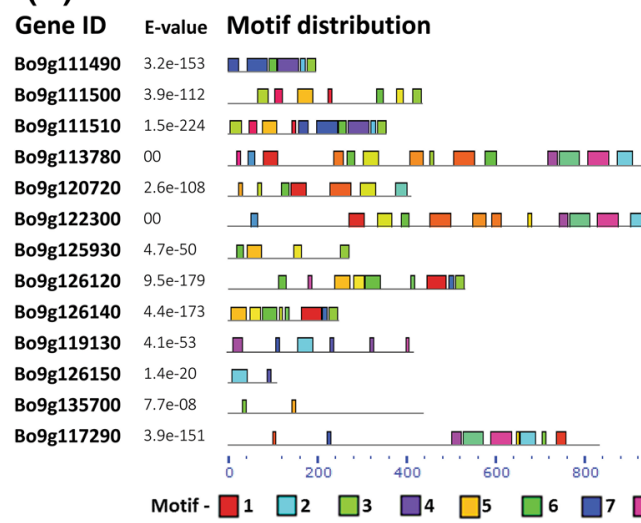

(B)

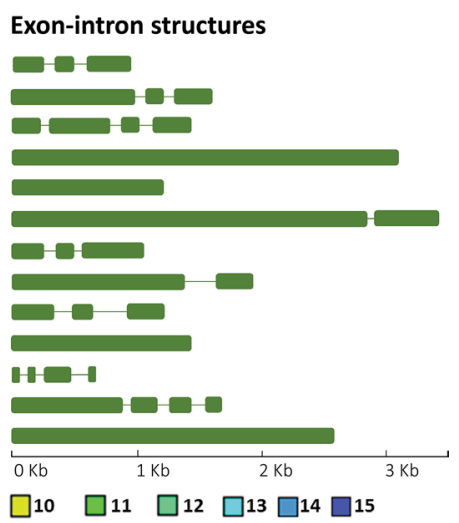

Fig. 4 Occurrence and distribution of protein motifs (a) and exonintron structures (b) of the LRR, CC, FBD, MAPK, and RLK genes within the collinear region of $B$. napus blackleg resistance gene LepR2' in B. oleracea. The length and position of motifs in the pro- tein sequences are indicated using coloured blocks. Exons and introns are represented by green boxes and green lines, respectively, and the genomic length is indicated at the bottom. Details of the motif sequences are shown in Table S3

\subsection{Chromosomal location and microsynteny relationship of the identified $L R R, C C, F B D$, MAPK, and RLK domain-containing genes} Bo9g117290 (Fig. 4b).

Along with these 13 genes, another gene, Bo9g169800, encoding a receptor-like protein was also included for differential expression analysis against $L$. maculans isolates. This gene is orthologous to JX880110 (sequence similarity $92.5 \%$, e-value $=0.0$ ), the first ever cloned B. napus blackleg resistance gene LepR3 on chromosome A10 (Larkan et al. 2013). This gene is included for expression analysis, since it is known to confer resistance in B. napus and is located $8.15 \mathrm{Mbp}$ downstream of the LepR2' collinear region in $B$. oleracea.
The 13 selected LRR, CC, FBD, MAPK, and RLK domain-containing genes were evenly distributed throughout the LepR2' collinear region in B. oleracea (Fig. 2b). No distinct clustering of the genes was observed, except groups of three genes were found to be closely located: genes Bo9g111490, Bo9g111500 and Bo9g111510 located at $36.2 \mathrm{Mbp}$ (at the flanking end of the collinear region) and genes Bo9g126120, Bo9g126140, and Bo9g126150 located at 39.6 Mbp (at approximately the center of the collinear region). 
Microsynteny relationship analysis of the identified 13 genes of $B$. oleracea (a C-genome crop) with $B$. rapa (an A-genome crop), B. nigra (a B-genome crop), and A. thaliana identified seven orthologous gene pairs with $A$. thaliana, distributed across all five chromosomes of $A$. thaliana (Fig. 2c). For the A-genome (B. rapa), fifteen orthologous gene pairs were identified: a maximum of six pairs with chromosome A10, followed by three and two pairs with A03 and $\mathrm{A} 02$, respectively, and one pair with each of chromosomes A01, A05, A06, and A07. With B. nigra (a B-genome crop), a total of seven orthologous gene pairs were observed. These results suggest a high microsyntenic relationship for the 13 identified LRR, CC, FBD, MAPK, and RLK genes among $\mathrm{A}-, \mathrm{B}-$, and $\mathrm{C}$-genome crops.

\subsection{Expression profiling of the identified LRR, CC, TIR, FBD, MAPK, and RLK domain-containing genes}

Expression of the identified LRR, CC, FBD, MAPK, and RLK domain-containing genes was determined in the resistant and susceptible cabbage genotypes at different time points after inoculation with $L$. maculans isolates $00-100 \mathrm{~s}$ and 03-02 s using gene-specific primers (Table S4). Hierarchical clustering of the expressions of these genes in a heatmap representation identified a cluster of seven genes (Bo9g126150, Bo9g117290, Bo9g111490, Bo9g126120, Bo9g111510, Bo9g111500, and Bo9g126140) that showed significant differential expression in the resistant line SCNU-98 comparted to that in the susceptible line SCNU72 (Fig. 5). Among these seven genes, only two genes, Bo9g126150 and Bo9g111490, were induced in the resistant line against both isolates, whereas the remaining five genes were only induced against the isolate 00-100 s (Fig. 5, 6).

A common feature of these seven genes is that they were significantly induced in the resistant line at $6 \mathrm{~h}$ following inoculation with $L$. maculans isolate $00-100 \mathrm{~s}$. Against this isolate, only the gene Bo9g126150 was consistently highly expressed in the resistant line at later time points as well (i.e., at $24 \mathrm{~h}$ and $48 \mathrm{~h}$ following inoculation) (Fig. 6). The gene Bo9g117290 also showed higher expression at $24 \mathrm{~h}$, but it did not show significantly higher expression at $48 \mathrm{~h}$ following inoculation. The remaining five genes did not show distinctively increased expressions after $6 \mathrm{~h}$ of inoculation. Against the isolate 03-02 s, genes Bo9g126150 and Bo9g 111490 were only induced at $24 \mathrm{~h}$ following inoculation.

Among the significantly expressed genes, the highest expression levels in the resistant line SCNU-98 were observed for the gene Bo9g117290 at $6 \mathrm{~h}$ ( 11-fold) and
Fig. 5 Expression patterns of the LRR, CC, FBD, MAPK, and RLK domain-containing genes within the collinear region of $B$. napus blackleg resistance gene LepR2' in B. oleracea at different time points following inoculation with $L$. maculans isolates 03-02 s and 00-100 s in the cotyledons of resistant (SCNU98) and susceptible (SCNU-72) cabbage lines, as determined by qRT-PCR. Gene expression values were $\log 2$-transformed and hierarchically clustered. Colour figure available online. The gene Bo9g169800 is located 8.15 Mbp downstream of the LepR2' collinear region. This is included for expression analysis since it is orthologous to JX880110, the cloned gene of B. napus blackleg resistance locus LepR3 (Larkan et al. 2013)

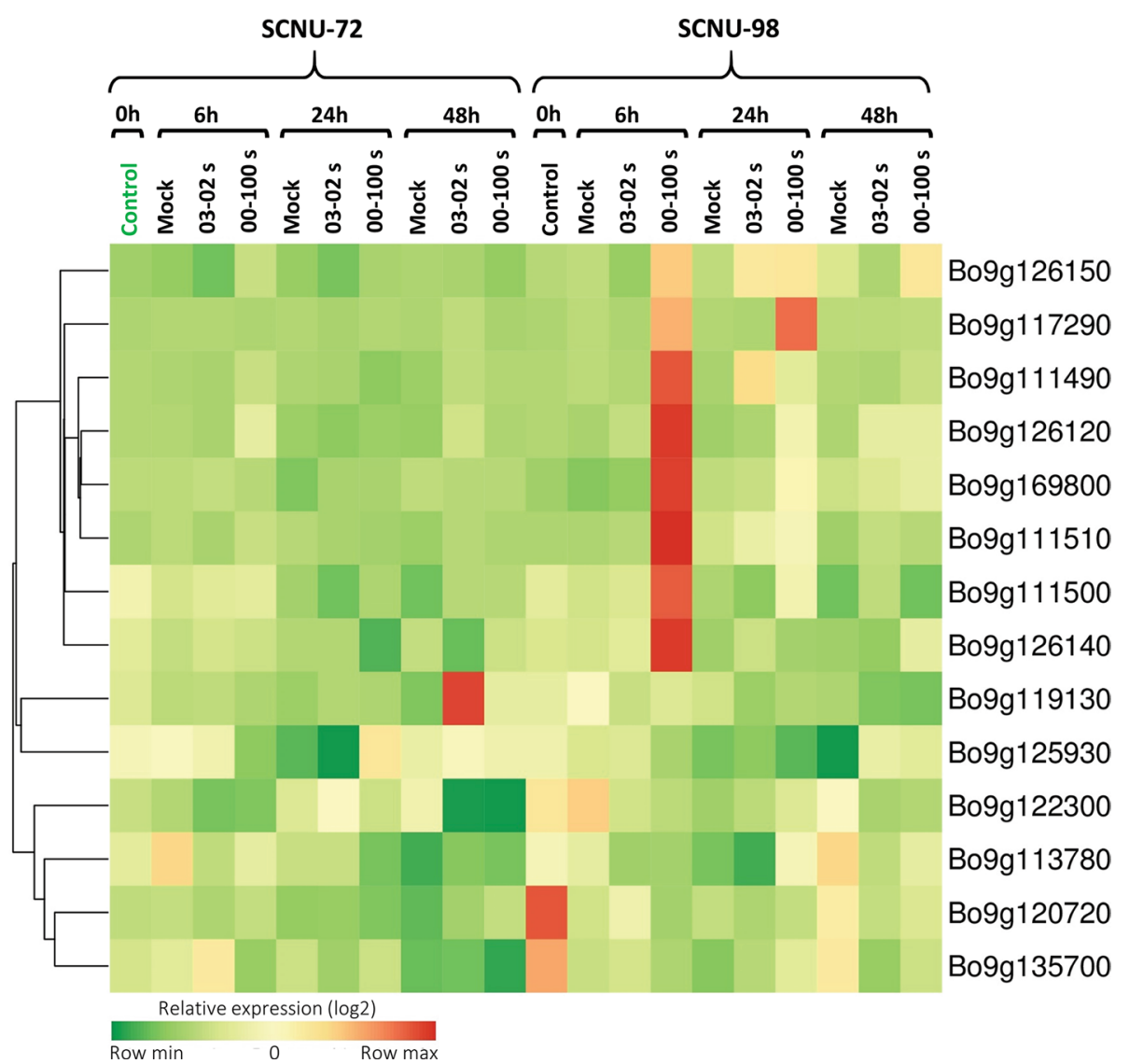




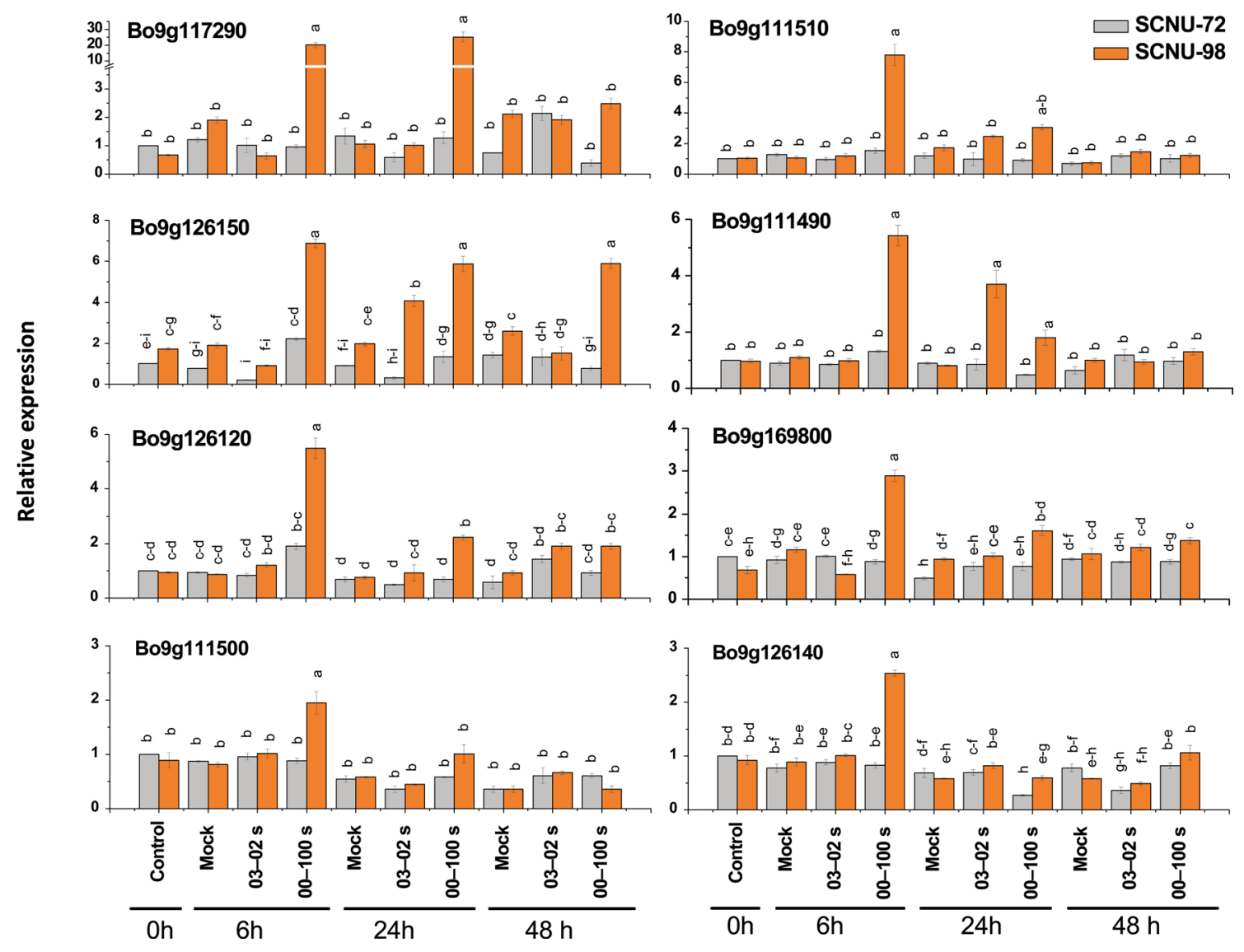

Fig. 6 Differential expression of the LRR, CC, FBD, MAPK, and RLK domain-containing genes within the collinear region of $B$. napus blackleg resistance gene LepR2' in B. oleracea at different time points following inoculation with $L$. maculans isolates $03-02 \mathrm{~s}$ and $00-100 \mathrm{~s}$ in the cotyledons of resistant (SCNU-98) and susceptible (SCNU-72) cabbage lines. Error bars represent standard devia-

$24 \mathrm{~h}$ ( 24-fold) followed by the gene Bo9g 111510 ( sevenfold) at $6 \mathrm{~h}$ after inoculation by the isolate $00-100 \mathrm{~s}$ (Fig. 6).

Among the genes induced by both isolates, gene Bo9g126150 showed $\sim$ three-fourfold higher expression at 6,24 , and $48 \mathrm{~h}$ against isolate $00-100 \mathrm{~s}$ and $\sim$ twofold higher expression against isolate $03-02 \mathrm{~s}$ at $24 \mathrm{~h}$. On the other hand, the gene Bo9g111490 was highly expressed against isolate $00-100 \mathrm{~s}$ only at $6 \mathrm{~h}$ ( fivefold) and against isolate $03-02 \mathrm{~s}$ at $24 \mathrm{~h}$ ( fivefold) (Fig. 6).

\section{Discussion}

This study reports the identification of putative disease resistance-related LRR, CC, FBD, MAPK, and RLK-domain containing genes within the collinear region of $B$. napus blackleg resistance locus LepR2' in B. oleracea, while also determining the potential association of those genes with blackleg resistance in cabbage. tion of the means of three independent replicates. Different letters above the bars indicate statistically significant differences based on Tukey's pairwise comparisons. The gene Bo9g169800 is located 8.15 Mbp downstream of the LepR2' collinear region. This is included for expression analysis since it is orthologous to JX880110, the cloned gene of B. napus blackleg resistance locus LepR3 (Larkan et al. 2013)

R-gene-mediated resistance to L. maculans in Brassica family crops is largely governed by compatible 'gene-forgene' interactions, where a specific avirulence gene (Avr) of the pathogen is recognized by corresponding R-gene of the host (Ansan-Melayah et al. 1998; Flor 1971; Williams and Delwiche 1980). The cabbage inbred line SCNU-98 displayed a high resistance response against both $L$. maculans isolates, 03-02 s and 00-100 s, at the cotyledon stage. However, the specific R-locus that may confer resistance in this Korean cabbage inbred line could not be determined due to the lack of differential set of $L$. maculans isolates having different $A v r$ gene profiles (owing to strict import restrictions on L. maculans strains). Mapping the R-genes in segregating populations could be an effective approach, but this is also time consuming, resource demanding, and expensive (Delourme et al. 2018; Miles and Wayne 2008).

A comprehensive meta-analysis of 314 cloned plant $\mathrm{R}$-genes indicated nine different molecular mechanisms of resistance, which were mainly manifested by NBS, LRR, 
TIR, CC, and RLP/RLKs domains (Kourelis and van der Hoorn 2018). Genome-wide, genes containing such disease resistance-related domains are known for major plant species including rice, potato, soybean, cucumber, melon, peach, grape, apple, and Arabidopsis [reviewed in 57-59]. Several studies have identified genome-wide NBS-LRR genes in major Brassicaceae crops (Alamery et al. 2018; Fu et al. 2019; Golicz et al. 2016; Yu et al. 2014), of which Alamery et al. 2018(Alamery et al. 2018) reported the maximum number of NBS-LRR genes in B. rapa (249), B. oleracea (443), and B. napus (641). The recent pan-genome of $B$. oleracea used an improved pipeline for genome assembly and resistance gene analog (RGA) candidate prediction, identifying a total of 213 RLP, 556 NBS-LRR, and 901 RLK genes (Bayer et al. 2019). A total of 97 NBS-encoding genes were reported to be orthologous between $B$. oleracea and $B$. napus (Fu et al. 2019). We reasoned that mining such disease resistance-related, domain-containing genes within the collinear regions of known B. napus $\mathrm{R}$-loci in a $\mathrm{C}$-genome and profiling their differential expressions in the resistant versus susceptible cabbage genotypes might lead to the identification of putative candidate genes for blackleg resistance, which upon validation by functional analysis, could be useful for improving blackleg resistance in elite cabbage cultivars. In this study, we focused on B. napus blackleg resistance locus LepR2', since both isolates (against which the cabbage inbred line SCNU-98 were resistant) contain corresponding avirulence gene (Robin et al. 2017). This suggests the existence of the corresponding R-gene in this line. The locus LepR2', flanked by markers sR8548a and sN2551b on B. napus linkage group A10, was originally introgressed from $B$. rapa subsp. sylvestris via interspecific hybridization, and its complete expression in B. napus has been speculated to require some chromosomes and genes from the $\mathrm{C}$-genome (Yu et al. 2012). This locus is allelic to the previously identified locus LepR2 and is an incompletely dominant gene that provides strong resistance against a range of $L$. maculans isolates in B. napus (Yu et al. 2005, 2012).

A total of 13 genes were identified within the collinear region of LepR2' in B. oleracea which contain at least one of the LRR, CC, FBD, MAPK, and RLK domains. Among these genes, the receptor like protein kinase gene Bo9g117290 showed the highest expression level in the resistant line SCNU-98 against the isolate 00-100 s ( 11and 24-fold induction at $6 \mathrm{~h}$ and $24 \mathrm{~h}$ following inoculation, respectively). RLKs are major component of membranelocalized pattern-recognition receptors (PRRs) that mediate the first line of plant defence by recognizing the pathogen-associated molecular patterns (PAMPs) and activating PAMP-triggered immunity (PTI) (Jones and Dangl 2006). Sixty out of 314 cloned plant's R-genes have been reported to be RLKs/RLPs (Kourelis and van der Hoorn 2018). RLKs were found to be involved in both broad-spectrum, elicitor-initiated defence responses such as FLS2 (FLAGELLIN SENSITIVE 2) in Arabidopsis and pathogen-specific, dominant R-gene-mediated defence responses, such as Xa21 in rice (Sekhwal et al. 2015; Goff and Ramonell 2007; Liu et al. 2017). The gene $F L S 2$ was the first RLK gene found to be involved in perception of the bacterial elicitor Flagellin in Arabidopsis (Gómez-Gómez and Boller 2000), and the gene Xa21 conferred resistance to race 6 of Xanthomonas oryzae pv. oryzae, which causes bacterial blight in rice (Song et al. 1995). Comparison of functional domains revealed that our putative candidate gene Bo9g117290 also contain a cytoplasmic serine/threonine kinase domain along with an LRR domain.

Among known blackleg resistance loci in Brassica genomes, only two R-loci, namely LepR 3 and $R \operatorname{lm} 2$, have been cloned so far. These two loci are confirmed to be allelic and to encode LRR-RLP genes (Larkan et al. 2013; Larkan et al. 2015). The corresponding orthologue of this LRR-RLP gene in C-genome is the gene Bo9g169800, which is located approximately $8.15 \mathrm{Mbp}$ downstream of the LepR2' collinear region in $B$. oleracea (Fig. 2b). We have investigated its expression and found that it is only induced by $\sim$ twofold in the resistant line SCNU-98 against the isolate 00-100 s at $6 \mathrm{~h}$, which is much less than the 11-24-fold higher expression of the RLK domain-containing gene Bo9g117290 against the isolate at 6-24 $\mathrm{h}$ after inoculation (Fig. 6).

The two most well-known RLK genes, FLS2 and BAK1 (BRI1-associated receptor kinase 1) are known to initiate the MAP kinase cascade upon recognition of the bacterial PAMP flagellin, flg22 (Deslandes and Rivas 2012; Chinchilla et al. 2007; Kim et al. 2013). Two MAP kinase genes, Bo9g119130 and Bo9g126150, were found within the LepR2' collinear region in B. oleracea. In particular, the gene Bo9g126150 was highly expressed against both isolates: three-fourfold against isolate $00-100 \mathrm{~s}$ at all time points following inoculation and $\sim$ twofold against isolate $03-02 \mathrm{~s}$ at $6 \mathrm{~h}$, indicating a putative role in blackleg resistance.

Among the 13 selected genes within the collinear region of LepR2' in B. oleracea, six genes had an F-box domain (FBD) along with an LRR domain (Fig. 3). Of these, two genes were highly expressed in the resistant line SCNU-98, Bo9g111510 only against isolate $00-100 \mathrm{~s}$ at $6 \mathrm{~h}$ following inoculation ( sevenfold; the second highest expression among the 13 genes) and Bo9g111490 against both isolates ( fivefold, against isolate $00-100 \mathrm{~s}$ at $6 \mathrm{~h}$ and against isolate $03-02 \mathrm{~s}$ at $24 \mathrm{~h}$ following inoculation). Several F-box proteins are known to play roles in plant defence against phytopathogens. For example, MAX2 contributed to resistance against Pectobacterium carotovorum and Pseudomonas syringae in Arabidopsis (Piisilä et al. 2015), CPRl was involved in controlling the stability of plant NBS-LRR proteins in Arabidopsis (Cheng et al. 2011), and ACRE189/ 
$A C I F 1$ was involved in activating defence responses and regulating cell death during recognition of Pseudomonas syringae pv. tabaci and Cladosporium fulvum in tobacco and tomato (van den Burg et al. 2008).

\section{Conclusion}

In this study, genes containing putative disease resistancerelated domains were identified in the collinear region of $B$. napus blackleg resistance locus LepR2' in B. oleracea. Very high expression of the LRR-RLK gene Bo9g117290 and the LRR-FBD gene Bo9g111510 against the L. maculans isolate 00-100 s, and high expression of the LRR-MAP kinase gene Bo9g126150 and the LRR-FBD gene Bo9g111510 against both isolates in the resistant cabbage line suggest putative roles of these genes in conferring resistance to blackleg in B. oleracea. A mapping-based approach will be necessary to identify if more than one locus is involved. In addition, functional analyses of these genes will be helpful in identifying the key gene(s) conferring resistance to blackleg in cabbage.

Acknowledgements This study was supported by the Golden Seed Project (Grant Number: 213007-05-4-SBG100), Center for Horticultural Seed Development, Ministry of Agriculture, Food and Rural Affairs in the Republic of Korea (MAFRA). We thank Nicholas J. Larkan and Hossein Borhan of Agriculture and Agri-Food Canada (AAFC), Saskatoon for providing the Leptosphaeria maculans isolates; Manosh Kumar Biswas, Department of Genetics and Genome Biology, University of Leicester, UK for his technical assistance with microsynteny analysis. We also thank anonymous reviewers for their helpful suggestions to improve the manuscript.

Author contribution Conceptualization and supervision: ISN, JIP and HTK; in silico analysis: MJF, SN and MRH; assisting in sample preparation and RNA extraction: HJJ and AHKR; all experiments: MJF; data analysis, interpretation, manuscript editing and review: MJF and MRH; project administration and funding acquisition: ISN. All authors read the article and approved the manuscript.

Data availability The datasets generated and/or analysed during the current study are available from the corresponding author on reasonable request.

\section{Compliance with ethical standards}

Conflict of interest The authors declare that they have no conflict of interest. This article does not contain any studies with human participants or animals performed by any of the authors.

Open Access This article is licensed under a Creative Commons Attribution 4.0 International License, which permits use, sharing, adaptation, distribution and reproduction in any medium or format, as long as you give appropriate credit to the original author(s) and the source, provide a link to the Creative Commons licence, and indicate if changes were made. The images or other third party material in this article are included in the article's Creative Commons licence, unless indicated otherwise in a credit line to the material. If material is not included in the article's Creative Commons licence and your intended use is not permitted by statutory regulation or exceeds the permitted use, you will need to obtain permission directly from the copyright holder. To view a copy of this licence, visit http://creativecommons.org/licenses/by/4.0/.

\section{References}

Alamery S, Tirnaz S, Bayer P, Tollenaere R, Chaloub B, Edwards D, Batley J (2018) Genome-wide identification and comparative analysis of NBS-LRR resistance genes in Brassica napus. Crop Pasture Sci 69:79-93

Ananga AO, Cebert E, Soliman K, Kantety R, Pacumbaba RP, Konan K (2006) RAPD markers associated with resistance to blackleg disease in Brassica species. J Biotechnol 5:2041-2048

Ansan-Melayah D, Balesdent MH, Delourme R, Pilet ML, Tanguy X, Renard M, Rouxel T (1998) Genes for race-specific resistance against blackleg disease in Brassica napus L. Plant Breed 117:373-378

Badawy HMA, Hoppe H, Koch E (1991) Differential reactions between the genus Brassica and aggressive single spore isolates of Leptosphaeria maculans. J Phytopathol 131:109-119

Balesdent MH, Attard A, Kühn ML, Rouxel T (2002) New avirulence genes in the phytopathogenic fungus Leptosphaeria maculans. Genet Resist 92:1122-1133

Bayer PE, Golicz AA, Tirnaz S, Chan CKK, Edwards D, Batley J (2019) Variation in abundance of predicted resistance genes in the Brassica oleracea pangenome. Plant Biotechnol J 17:789-800

Bohman S, Wang M, Dixelius C (2002) Arabidopsis thaliana-derived resistance against Leptosphaeria maculans in a Brassica napus genomic background. Theor Appl Genet 105:498-504

Chalhoub B, Denoeud F, Liu S, Parkin IAP, Tang H, Wang X, Chiquet J, Belcram H, Tong C, Samans B (2014) Early allopolyploid evolution in the post-Neolithic Brassica napus oilseed genome. Science 345:950-953

Cheng YT, Li Y, Huang S, Huang Y, Dong X, Zhang Y, Li X (2011) Stability of plant immune-receptor resistance proteins is controlled by SKP1-CULLIN1-F-box (SCF)-mediated protein degradation. Proc Natl Acad Sci 108:14694-14699

Cheng F, Wu J, Liang J, Wang X (2014) Genome triplication drove the diversification of Brassica plants. Hortic Res 1:115-120

Chèvre AM, Barret P, Eber F, Dupuy P, Brun H, Tanguy X, Renard M (1997) Selection of stable Brassica napus-B. juncea recombinant lines resistant to blackleg (Leptosphaeria maculans).1. Identification of molecular markers, chromosomal and genomic origin of the introgression. Theor Appl Genet 95:1104-1111

Chinchilla D, Zipfel C, Robatzek S, Kemmerling B, Nürnberger T, Jones JDG, Felix G, Boller T (2007) A flagellin-induced complex of the receptor FLS2 and BAK1 initiates plant defence. Nature 448:497

Christianson JA, Rimmer SR, Good AG, Lydiate DJ (2006) Mapping genes for resistance to Leptosphaeria maculans in Brassica juncea. Genome 41:30-41

Delourme R, Pilet-Nayel ML, Archipiano M, Horvais R, Tanguy X, Rouxel T, Brun H, Renard M, Balesdent MH (2004) A cluster of major specific resistance genes to Leptosphaeria maculans in Brassica napus. Phytopathology 94:578-583

Delourme R, Chevre AM, Brun H, Rouxel T, Balesdent MH, Dias JS, Salisbury P, Biop UMR, Cedex LR, De St-cyr R (2006) Major gene and polygenic resistance to Leptosphaeria maculans in oilseed rape (Brassica napus). Eur J Plant Pathol 114:41-52

Delourme R, Laperche A, Bouchet A, Jubault M, Paillard S, Nesi $\mathrm{N}$ (2018) Genes and quantitative trait loci mapping for major 
agronomic traits in Brassica napus L. In: The Brassica napus Genome; Springer International Publishing, pp 41-85, ISBN 9783319436944

Deslandes L, Rivas S (2012) Catch me if you can: bacterial effectors and plant targets. Trends Plant Sci 17:644-655

Dilmaghani A, Balesdent MH, Rouxel T, Moreno-Rico O (2010) First report of Leptosphaeria biglobosa (blackleg) on Brassica oleracea (cabbage) in Mexico. Plant Dis 94:791

Ding G, Zhao Z, Liao Y, Hu Y, Shi L, Long Y, Xu F (2012) Quantitative trait loci for seed yield and yield-related traits, and their responses to reduced phosphorus supply in Brassica napus. Ann Bot 109:747-759

Ellis J, Dodds P, Pryor T (2000) Structure, function and evolution of plant disease resistance genes. Curr Opin Plant Biol 3:278-284

Ferreira ME, Dias JS, Mengistu A, Williams PH (1992) Screening of Portuguese cole landraces (Brassica oleracea L.) with Leptosphaeria maculans and Xanthomonas campestris pv. campestris. Euphytica 65:219-227

Fitt BDL, Hu BC, Li ZQ, Liu SY, Lange RM, Kharbanda PD, Butterworth MH, White RP (2008) Strategies to prevent spread of Leptosphaeria maculans (phoma stem canker) onto oilseed rape crops in China; costs and benefits. Plant Pathol 57:652-664

Flor HH (1971) Current status of the gene-for-gene concept. Annu Rev Phytopathol 9:275-296

Franzke A, Lysak MA, Al-Shehbaz IA, Koch MA, Mummenhoff K (2011) Cabbage family affairs: the evolutionary history of Brassicaceae. Trends Plant Sci 16:108-116

Fu Y, Zhang Y, Mason AS, Lin B, Zhang D, Yu H, Fu D (2019) NBSencoding genes in Brassica napus evolved rapidly after allopolyploidization and co-localize with known disease resistance loci. Front Plant Sci 10:1-18

Goff KE, Ramonell KM (2007) The role and regulation of receptor-like kinases in plant defense. Gene Regul Syst Biol 1:167-175

Golicz AA, Bayer PE, Barker GC, Edger PP, Kim HR, Martinez PA, Chan CKK, Severn-Ellis A, McCombie WR, Parkin IAP et al (2016) The pangenome of an agronomically important crop plant Brassica oleracea. Nat Commun 7:1-8

Gómez-Gómez L, Boller T (2000) FLS2: an LRR receptor-like kinase involved in the perception of the bacterial elicitor flagellin in Arabidopsis. Mol Cell 5:1003-1011

Hao L, Song P, Huangfu H, Li Z (2015) Genetic diversity and differentiation of Leptosphaeria biglobosa on oilseed rape in China. Phytoparasitica 43:253-263

Hong S-K, Kim W-G, Shin D-B, Choi H-W, Lee Y-K, Lee S-Y (2009) Occurrence of stem canker on rape caused by Leptosphaeria biglobosa in Korea. Plant Pathol J 25:294-298

Humpherson-Jones FM (1985) The incidence of Alternaria spp. and Leptosphaeria maculans in commercial brassica seed in the United Kingdom. Plant Pathol 34:385-390

Jones JDG, Dangl JL (2006) The plant immune system. Nature 444:323-329

Kim MH, Kim Y, Kim JW, Lee H-S, Lee WS, Kim S-K, Wang Z-Y, Kim S-H (2013) Identification of Arabidopsis BAK1-associating receptor-like kinase 1 (BARK1) and characterization of its gene expression and brassinosteroid-regulated root phenotypes. Plant Cell Physiol 54:1620-1634

Kourelis J, van der Hoorn RAL (2018) Defended to the Nines: 25 years of resistance gene cloning identifies nine mechanisms for $\mathrm{R}$ protein function. Plant Cell 30:285-299

Kutcher HR, Cross D, Nabetani K, Kirkham CL (2011) A large-scale survey of races of $L$. maculans occurring on canola in western Canada

Larkan NJ, Lydiate DJ, Parkin IAP, Nelson MN, Epp DJ, Cowling WA, Rimmer SR, Borhan MH (2013) The Brassica napus blackleg resistance gene LepR 3 encodes a receptor-like protein triggered by the Leptosphaeria maculans effector AVRLM1. New Phytol 197:595-605

Larkan NJ, Ma L, Borhan MH (2015) The Brassica napus receptor-like protein RLM2 is encoded by a second allele of the LepR3/Rlm2 blackleg resistance locus. Plant Biotechnol J 13:1-10

Leflon M, Brun H, Eber F, Delourme R, Lucas MO, Vallée P, Ermel M, Balesdent MH, Chèvre AM (2007) Detection, introgression and localization of genes conferring specific resistance to Leptosphaeria maculans from Brassica rapa into B. napus. Theor Appl Genet 115:897-906

Li H, Kuo J, Barbetti MJ, Sivasithamparam K (2007a) Differences in the responses of stem tissues of spring-type Brassica napus cultivars with polygenic resistance and single dominant gene-based resistance to inoculation with Leptosphaeria maculans. Botany $85: 191-203$

Li H, Sivasithamparam K, Barbetti MJ (2007b) Soilborne ascospores and pycnidiospores of Leptosphaeria maculans can contribute significantly to blackleg disease epidemiology in oilseed rape (Brassica napus) in Western Australia. Australas Plant Pathol 36:439-444

Liu Z (2008) Strategies for managing Leptosphaeria maculans and Leptosphaeria biglobosa to decrease severity of phoma stem canker epidemics on winter oilseed rape. PhD Thesis, University of Hertfordshire

Liu J, Liu X, Dai L, Wang G (2007) Recent progress in elucidating the structure, function and evolution of disease resistance genes in plants. J Genet Genom 34:765-776

Liu Z, Latunde-Dada AO, Hall AM, Fitt BDL (2014a) Phoma stem canker disease on oilseed rape (Brassica napus) in China is caused by Leptosphaeria biglobosa 'brassicae'. Eur J Plant Pathol 140:841-857

Liu S, Liu Y, Yang X, Tong C, Edwards D, Parkin IAP, Zhao M, Ma J, Yu J, Huang S (2014b) The Brassica oleracea genome reveals the asymmetrical evolution of polyploid genomes. Nat Commun 5:3930

Liu PL, Du L, Huang Y, Gao SM, Yu M (2017) Origin and diversification of leucine-rich repeat receptor-like protein kinase (LRRRLK) genes in plants. BMC Evol Biol 17:1-16

Marcroft SJ, Wratten N, Purwantara A, Salisbury PA, Potter TD, Barbetti MJ, Khangura R, Howlett BJ (2002) Reaction of a range of Brassica species under Australian conditions to the fungus, Leptosphaeria maculans, the causal agent of blackleg. Aust J Exp Agric 42:587-594

Mendes-Pereira E, Balesdent Ne M-H, Brun H, Rouxel T (2003) Molecular phylogeny of the Leptosphaeria maculans-L. biglobosa species complex. Mycol Res 107:1287-1304

Meng X, Zhang S (2013) MAPK cascades in plant disease resistance signaling. Annu Rev Phytopathol 51:245-266

Meyers BC, Dickerman AW, Michelmore RW, Sivaramakrishnan S, Sobral BW, Young ND (1999) Plant disease resistance genes encode members of an ancient and diverse protein family within the nucleotide-binding superfamily. Plant J 20:317-332

Miles CM, Wayne M (2008) Quantitative trait locus (QTL) analysis. Nat Educ 1:208

Pang ECK, Halloran GM (1996) The genetics of blackleg [Leptosphaeria maculans (Desm.) Ces. et De Not.] resistance in rapeseed (Brassica napus L.). Theor Appl Genet 93:941-949

Piisilä M, Keceli MA, Brader G, Jakobson L, Jõesaar I, Sipari N, Kollist H, Palva ET, Kariola T (2015) The F-box protein MAX2 contributes to resistance to bacterial phytopathogens in Arabidopsis thaliana. BMC Plant Biol 15:53

Piliponytè-Dzikienè A, Andriūnaitė E, Petraitienė E, Brazauskienė I, Statkevičiūtè G, Brazauskas G (2015) Genetic diversity and occurrence of Leptosphaeria spp. on Brassica oleracea and $B$. napus in Lithuania. J Plant Pathol 97(2):265-271 
Plieske J, Struss D, Röbbelen G (1998) Inheritance of resistance derived from the B-genome of Brassica against Phoma lingam in rapeseed and the development of molecular markers. Theor Appl Genet 97:929-936

Rimmer SR, van den Berg CGJ (1992) Resistance of oilseed Brassica spp. to blackleg caused by Leptosphaeria maculans. Can J Plant Pathol 14:56-66

Robin AHK, Larkan NJ, Laila R, Park JI, Ahmed NU, Borhan H, Parkin IAP, Nou IS (2017) Korean Brassica oleracea germplasm offers a novel source of qualitative resistance to blackleg disease. Eur J Plant Pathol 149:611-623

Rouxel T, Balesdent MH (2005) The stem canker (blackleg) fungus, Leptosphaeria maculans, enters the genomic era. Mol Plant Pathol 6:225-241

Sekhwal MK, Li P, Lam I, Wang X, Cloutier S, You FM (2015) Disease resistance gene analogs (RGAs) in plants. Int J Mol Sci 16:19248-19290

Song W-Y, Wang G-L, Chen L-L, Kim H-S, Pi L-Y, Holsten T, Gardner J, Wang B, Zhai W-X, Zhu L-H (1995) A receptor kinase-like protein encoded by the rice disease resistance gene, Xa21. Science 270:1804-1806

Stein A, Wittkop B, Liu L, Obermeier C, Friedt W, Snowdon RJ (2013) Dissection of a major QTL for seed colour and fibre content in Brassica napus reveals colocalization with candidate genes for phenylpropanoid biosynthesis and flavonoid deposition. Plant Breed 132:382-389

van den Burg HA, Tsitsigiannis DI, Rowland O, Lo J, Rallapalli G, Maclean D, Takken FLW, Jones JDG (2008a) The F-box protein ACRE189/ACIF1 regulates cell death and defense responses activated during pathogen recognition in tobacco and tomato. Plant Cell 20:697-719

van den Burg HA, Tsitsigiannis DI, Rowland O, Lo J, Rallapalli G, MacLean D, Takken FLW, Jones JDG (2008b) The F-Box protein ACRE189/ACIF1 regulates cell death and defense responses activated during pathogen recognition in Tobacco and tomato. Plant Cell Online 20:697-719

West JS, Kharbanda PD, Barbetti MJ, Fitt BDL (2001) Epidemiology and management of Leptosphaeria maculans (phoma stem canker) on oilseed rape in Australia, Canada and Europe. Plant Pathol 50:10-27
Williams PH, Delwiche PA (1980) Screening for resistance to blackleg of crucifers in the seedling stage. In: Proceedings of the Eucarpia'Cruciferae 1979' conference, 1, 2, 3 October 1979, Wageningen.; Foundation for Agricultural Plant Breeding., pp $164-170$

Wu J, Cai G, Tu J, Li L, Liu S, Luo X, Zhou L, Fan C, Zhou Y (2013) Identification of QTLs for resistance to Sclerotinia stem rot and BnaC. IGMT5. a as a candidate gene of the major resistant QTL SRC6 in Brassica napus. PLoS ONE 8:e67740

Yu F, Lydiate DJ, Rimmer SR (2005) Identification of two novel genes for blackleg resistance in Brassica napus. Theor Appl Genet 110:969-979

Yu F, Lydiate DJ, Gugel RK, Sharpe AG, Rimmer SR (2012) Introgression of Brassica rapa subsp. sylvestris blackleg resistance into $B$. napus. Mol Breed 30:1495-1506

Yu F, Gugel RK, Kutcher HR, Peng G, Rimmer SR (2013) Identification and mapping of a novel blackleg resistance locus LepR4 in the progenies from Brassica napus $\times$ B. rapa subsp. sylvestris. Theor Appl Genet 126:307-315

Yu J, Tehrim S, Zhang F, Tong C, Huang J, Cheng X, Dong C (2014) Genome-wide comparative analysis of NBS-encoding genes between Brassica species and Arabidopsis thaliana. BMC Genom $15: 1-18$

Zhang X, Fernando WGD (2018) Insights into fighting against blackleg disease of Brassica napus in Canada. Crop Pasture Sci 69:40-47

Zhang X, White RP, Demir E, Jedryczka M, Lange RM, Islam M, Li ZQ, Huang YJ, Hall AM, Zhou G (2014) Leptosphaeria spp., phoma stem canker and potential spread of L. maculans on oilseed rape crops in China. Plant Pathol 63:598-612

Zhao J, Huang J, Chen F, Xu F, Ni X, Xu H, Wang Y, Jiang C, Wang H, Xu A (2012) Molecular mapping of Arabidopsis thaliana lipidrelated orthologous genes in Brassica napus. Theor Appl Genet 124:407-421

Publisher's Note Springer Nature remains neutral with regard to jurisdictional claims in published maps and institutional affiliations. 